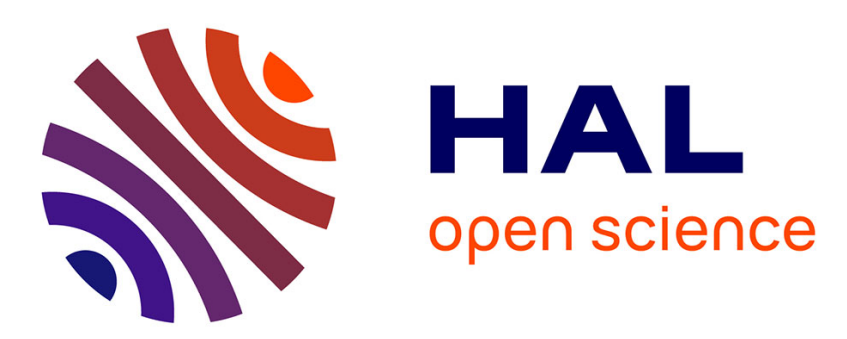

\title{
Boundary work between research communities. Culture and power in a French nanosciences and nanotechnology hub
}

Morgan Jouvenet

\section{- To cite this version:}

Morgan Jouvenet. Boundary work between research communities. Culture and power in a French nanosciences and nanotechnology hub. Information sur les Sciences Sociales / Social Sciences Information, 2013, 52 (1), pp.134 -158. hal-01088656

\section{HAL Id: hal-01088656 https://hal.science/hal-01088656}

Submitted on 28 Nov 2014

HAL is a multi-disciplinary open access archive for the deposit and dissemination of scientific research documents, whether they are published or not. The documents may come from teaching and research institutions in France or abroad, or from public or private research centers.
L'archive ouverte pluridisciplinaire HAL, est destinée au dépôt et à la diffusion de documents scientifiques de niveau recherche, publiés ou non, émanant des établissements d'enseignement et de recherche français ou étrangers, des laboratoires publics ou privés. 


\title{
Boundary work between research communities: \\ Culture and power in a French nanosciences and nanotechnology hub
}

\author{
Morgan Jouvenet
}

CNRS, Laboratoire Printemps

\begin{abstract}
Today, nanoscience and nanotechnology (NS/T) is one of the most visible domains of scientific activity. Its promises rest especially on a convergence dynamics that brings various research communities closer together. This convergence is interdisciplinary, but it also renews links between applied and basic science. Nanoscale-related folk myths and economic expectations are well documented, as are interventions of policymakers. Lab-level relations have on the other hand been less studied. Based on a qualitative study conducted in one of France's main NS/T centres, this article shows how researchers experience boundaries in the workplace. Indeed, as local physicists are prompted to plan heterogeneous projects, they stress the importance of cultural and professional distinctions between local research communities. If Shinn's 'regimes of knowledge production' offer useful conceptual tools to make sense of interactions and distinctions in this science and technology hub, the cultural dimension of exchanges and resistances has nevertheless to be emphasized in this framework. For the interviewed scientists. professional boundary work has furthermore a clear political meaning, while their collective rhetoric is also a way to claim credit in the local competition for institutional favours.
\end{abstract}

\section{Keywords}

boundary work, culture, nanosciences, science

\footnotetext{
Corresponding author:

Morgan Jouvenet, Centre National de la Recherche Scientifique, Laboratoire Printemps, 47 Boulevard Vauban, 78047 Guyancourt cedex, France.

Email:morgan.jouvenet@printemps.uvsq.fr
} 


\section{Résumé}

Les nanosciences et nanotechnologies (NS/T) constituent l'un des domaines d'activité scientifique les plus visibles aujourd'hui. Ses promesses reposent notamment sur une dynamique de convergence rapprochant diverses communautés de chercheurs. Cette convergence est interdisciplinaire, mais elle concerne aussi les rapports entre science fondamentale et science appliquée. Si la mythologie populaire associée aux manipulations de la matière à l'échelle nanométrique commence à être bien documentée, tout comme l'intérêt qu'elles suscitent auprès des acteurs industriels et politiques, les espaces et les relations de travail de leurs instigateurs font plus rarement l'objet de travaux sociologiques. A partir d'une enquête menée dans l'un des principaux pôles de la recherche française en NS/T, cet article montre comment les scientifiques considèrent et conçoivent les frontières qui marquent leur monde professionnel. Incités à s'inscrire dans des projets 'hybrides', ils soulignent en effet dans leurs discours l'importance des différences culturelles entre les communautés scientifiques locales. Le modèle des 'régimes de production du savoir' de T Shinn apparait très utile pour saisir la dynamique interactionnelle de ce carrefour scientifique et technologique. II laisse cependant encore trop peu de place à la dimension culturelle des échanges. Pour les physiciens interrogés. le travail des frontières a en outre un sens politique évident, et leur rhétorique collective est aussi un moyen de gagner du crédit vis-à-vis des pouvoirs publics locaux.

\section{Mots-clés}

approche transversaliste, cultures, frontières, nanosciences, science

\section{Introduction}

Today, nanoscience and nanotechnology (NS/T) constitute one of the most visible domains of scientific activity. ${ }^{1}$ All over the world, from Iran to the USA, including Europe and Korea, NS/T appears as a favoured terrain for the investing of public money. ${ }^{2}$ Each government aims to see its researchers and engineers produce nanotechnological innovations able to boost the national competitive advantage in the global industrial competition. This governmental backing is often strengthened by defence concerns, since 'nano-innovations' are also considered a key element in military research strategy. Those aims explicitly depend on the capacity to sustain a diversity of research and engineering activities in an environment organized to foster exchanges and transform ('transfer') knowledge into products. As such, NS/T offers a perfect case for debates about the patterns of opportunities and constraints typical of the contemporary 'knowledge economy'.

One of the most spectacular transformations effected by NS/T in the scientific world is said to be the erasure of gaps (or the blurring of frontiers) between research communities. Here the traditional fluidity of materials science (Bensaude-Vincent, 2004; Hoddeson, 2003) is said to have reached new heights. Observers of the "nano boom" indeed often say that nanoscale research 'naturally' pushes scientists to cross disciplinary boundaries, and makes scientists and industrials happy to cooperate in new 'hybrid' projects $-\mathrm{a}$ 'great convergence', an integrative process ${ }^{3}$ public authorities are eager to 
ease through new funding and buildings. In this perspective, NS/T is described as a perfect illustration of the 'seamless web' characteristic of the post-modern blurring of science and technology. Yet, if NS/T has already attracted interest from many social sciences scholars, few have conducted on-site laboratory studies, ${ }^{4}$ This relative lack of data on the organization of work on NS/T 'production' sites is regrettable, as it would make it possible to confirm or to mitigate general claims made at the macro level. For the same reasons, scientists' own perception of NS/T dynamics and their way of conceiving their involvements and investments in this domain have not been well documented thus far.

This article is based on qualitative empirical data produced in a French area dedicated to nano-activities and among researchers especially exposed to integrative policies (for historical and structural reasons developed in section 2.1). Observations and interviews made in seven physics laboratories constitute the main sources of the present analysis, which shows essentially that the pervasive 'seamless web' metaphor does not match the experience their scientists have of the heterogeneous network of cooperation they are involved in. The analysis draws on their discourses about the 'cultural differences' and the 'culture shocks' they experience in their work as 'nanophysicists'. Considering their account of cultural boundaries, this article also offers an examination of the distinctive practices of a scientific community, as they are performed in the course of the local NS/T dynamics. This community is not insulated from the world outside, nor it is simply part of a giant machine (like Callon \& Latour's famous 'Leviathan', 1981). On the contrary, I show how the community is involved in a jurisdictional negotiation with the local ecosystem, and how its members operate within the collective "political choreography" (Doing, 2009: 103) that takes place in and around the laboratories.

The importance these local scientists gave to cultural frontiers is based on a "phenomenology of group classification' that enables them to 'think of themselves as equivalent and similar to, or compatible with, others' (Lamont \& Molnar, 2002: 188). This applies especially to differences between 'applied' and 'basic' physics communities. Public innovation policy aims to bring the two communities closer, and in fact acts as a catalyst for 'boundary work' (Gieryn, 1983, 1999). ${ }^{5}$ Following recent studies conducted in NS/T laboratories (Baus, 2009) or elsewhere (Doing, 2009; Merz, 2006) that have been inspired by anthropology (c.g. Barth, 1969; or Glaeser, 2000), this article then shows how 'boundaries can be maintained despite close contact between groups' (Baus, 2009: 102) and offers a case for asserting that cultures and collective identities don't dissolve easily in network dynamics. As it will be shown, boundary work is indeed a way to negotiate collective identities (as competitors and collaborators) in this arena, and reveals practices and discourses constitutive of the culture of the 'basic science' that was thriving in the laboratories studied here. Instead of consolidating the 'seamless web" hypothesis, my laboratory (cultural) study strives towards the "sociology of "everyday cosmopolitanism" - professional cosmopolitanism, here - outlined by Lamont \& Molnár (2002). Data collected in Grenoble then allow me to show how the "post-modern cultural primacy of technology over science (Forman, 2007) actually occurs and is experienced in particular NS/T labs, where the historian indicates it is spectacularly embodied (Forman, 2007: 10-12). If this article draws on the 'power of the cultural' (Forman, 2007: 68) in the understanding of those experiences, its argument also 
contrasts strongly with the complete abolition of the distinction between science and technology that is typical of NS/T studies ${ }^{\dagger}$ - local physicists show they are still two different games, with different rules and meanings. ${ }^{7}$ It contributes additional documentation of the indexicality of the distinction between science and technology, and answers the need to question the science and technology divides by "turning to communities of practices, with attention to who makes what distinction, where and why' (Bauchspies, Croissant \& Restivo, 2006: 7).

\section{Scientific communities and their cultural boundaries}

\section{I The study's field and methods}

This article is built upon observations and interviews carried out in a group of seven physics laboratories whose activities are embedded in the NS/T domain. All are located in Grenoble's 'scientific polygon', and belong to the 'basic science' department of one of the biggest French scientific organizations, the Commissariat à l'Energie Atomique (CEA). Their aim is mainly to create nano-objects and study their magnetic, electrical and optical proprieties. As the CEA is designed to develop a product or a technique from the very first idea to the industrial prototype, physicists in those labs receive clear and regular incentives to direct their research towards 'future applications in photonics, spintronics and nanoelectronics' (quadrennial report of the department to which the laboratories belong).

The CEA at Grenoble is a good place to study NS/T dynamics, since nano-activities recently became one of the major assets of the local research community (Vinck, 2010). Politicians, CEOs and scientific leaders decided to join forces to make Grenoble the French capital of the 'nanoworld', presenting their involvement and investments as a critical economic gamble (Hubert, Jouvenet \& Vinck, 2013). This elite partnership mocked as the techno-gratin by technophobic activists - is a well-known local tradition (Pestre, 1990), and its current members spread pro-nano narratives in the public space. 'No vision, no funding' (Hessenbruch, 2004: 142): here nanoscale activities lack none, ${ }^{8}$

Some 110 people work in the laboratories studied (half of them on a permanent basis). and the data gathered result mainly from a series of 37 in-depth interviews conducted between 2005 and 2007 with local researchers, technicians and managers. Interviewees were male and female, young and old, experimenters and simulations experts, but all were physicists or former physicists. ${ }^{9}$ The interviews focused on three main topics: NS/T (scientific and organizational) dynamics and its local embodiments; the evolution of French research policy; and their experience of cooperation with members of other research communities. During the interviews, the scientists were asked to cite major evolutions they thought had a big impact on their professional lives, and to give the interviewer concrete examples of these changes. The point was to elucidate links between micro and macro descriptions - as a way of testing morphological (the 'seamless web') or hierarchical (the 'primacy of technology over science') hypotheses. Those macro hypotheses are often based on an analysis made of the 'cultural values' defining large communities: data collected in the labs enabled us to complete this analytical dimension with ethnographic accounts of concrete practices and interactions. 
This study is also based on workspace observations and document analysis that filled 101 pages of a field notebook. I benefited, too, from reactions to presentations I made in the physics labs, and had access to data shared by a couple of colleagues also conducting ethnographic studies in the same scientific area. ${ }^{10}$

\subsection{Physicists' experiences of NS/T local convergent processes}

Their specialities have put the scientists in those laboratories in an excellent position to acknowledge the benefits of the "nano boom'." They are able to take advantage of it on the funding market, and explain how the prefix 'nano' became something of a magic component in their scientific projects (like 'electro' was in the 1950s; cf. Strauss \& Rainwater, 1962:9). But if they often express a clear awareness of the artificiality of nano labelling (it's 'trendy' said D4 ${ }^{12}$ ), many also concede the existence of a new scientific domain (Jouvenet, 2009). Some of them go so far as to evoke 'a new way of looking at the world', or a 'revolution' that will have lasting effects.

It's really a revolution, because it even changes the student's learning in college. Because it's a convergence point of different ... of physics, chemistry, biology, etc. It's the merging of technology, of microelectronics in the living ... (L6)

For them, the novelty is related to the gathering of physicists, chemists or biologists (especially) around the same objects and instruments. Yet a majority of interviewees insist that this convergence in the sense of the reunion of scientists of different disciplines in common projects - doesn't mean that they abandon their cultures and languages. ${ }^{13}$

Transversality is the big thing ... Innovations are now mainly brought through the mixing of cultures. That's what we do by marrying chemistry, biology or magnetism [physics] with electronics. The aim is for example to associate DNA molecules with electronic chips ... And for that you have to have double or triple cultures. (R23)

Now, we are working at the same scale. That changes things a lot, it's a profound revolution ... There are different cultures and methods, but ... we will work more and more together. (L19)

There is a convergence between us - who come from upside, from microtechnologies, ete., and who are going towards the nano [level] ... and people coming from the bottom - who build molecules and other things, and who are going up ... We are about to meet: chemists, biologists and physicists. There's a real movement in this direction, with real applications. (L24)

The characterization of modes of interaction among various scientific disciplines in NS/T is beyond this article's scope. However, one can note that scientists' descriptions of these relations correspond to the 'weak integration' and the 'combinatorial approach' described by T Shinn (Marcovich \& Shinn, 2010b: 635; Shinn, 2005), and add that the scientific convergence discussed during the interviews is initiated by people as much as 
induced by objects (on the variety of motives of scientific cooperation in these labs, see Jouvenet, 2012).

\subsection{Managerial and administrative sources of local NS/T convergent process}

The Grenoble data show that the formation of heterogeneous research teams is also heavily dependent on management and administrative incentives. This is obvious at the CEA Grenoble, where science policy leaders claim to bet on heterogeneity to foster industrially workable (and 'bankable') nano-innovations. Their aim is first to incite researchers to cross disciplinary boundaries. 'Today, breakthroughs are made more often at the interface between disciplines than inside a discipline', says J Therme, head of CEA Grenoble and chief local NS/T promoter. ${ }^{14}$ Funding and strategic programs developed here favour projects combining disciplines, often in a technological framework. ${ }^{15}$ A couple of the laboratories studied were for example involved in a priority project named 'Chimtronic', defined as an effort to 'mix chemistry and nano-electronics, basic and applied research'. In this project, scientists work on 'functionalized' molecules, nanowires and carbon nanotubes, with an explicit reference to the International Technology Roadmap for Semiconductors (ITRS).

The 'nanoworld' is a domain of 'strategic research' and 'generic technologies', where the 'orchestration policy for innovation' that emerged in the 1980s, based on the 'stimulation of [a] more intimate relationship, and active partnership' between science and industry (Elzinga, 2005: 548), has taken dramatic forms. It is indeed a domain where the 'enhanced relationship' between academic and industrial actors is overtly backed, and sustained by 'new organizational formats' dedicated to 'promote innovation', often described as key features of the modern scientific landscape (Etzkowitz, 2005: 88). As hinted in the final example of the previous paragraph, the local integrative process is also largely based on the rapprochement of private and public sectors - the very move that massively justifies large-scale public funding of NS/T. That is the purpose of creating organizational devices like the pôles de compétitivité (Minalogic at Grenoble) or C'Nanos (resources) regional centres: to compel the association of industrial and academic teams working on industrially promising projects. The main political aim in this field is obviously to link applied research and development (R\&D), as practised in the private sector (especially electronics manufacturers, in the Grenoble area), and basic or 'blue sky" research, as conducted in public laboratories (Robinson, Rip \& Mangematin, 2007).

Ten years ago, there was hardly any relation between the [Technology Department] and us. It has really completely changed ... It was two worlds that ignored each other. And now ...

Heterogeneous projects often owe more to incentives provided by actors outside the labs than to 'disciplinary traditions or long-standing legal frameworks' (Shrum, Genuth \& Chompalov, 2007: 65). This was especially true for twentieth-century electronics research (Collett, 2003), and appears also as a salient feature of nanoscale research, which famously benefited from powerful industrial and political incentives. 'The 
vigorous backing given to nanoscale research by the US National Nanotechnology Initiative in the year 2000 ', notably, "acted as a catalyst' at many levels (Marcovich \& Shinn, 2010a: 232). Nanoscale research globally tends to stress again that 'there is probably no better way to stimulate researchers to reconsider their working relations than by creating a new funding category in which to compete' (Shrum, Genuth \& Chompalov, 2007: 30), and in Grenoble incentives indeed take the form of various funding programs. This is for instance done through Institut Carnot labelling, which offers financial support for 'knowledge transfer' projects, and also through Minalogic. But the main structural innovation of the latest years was the building and opening, in 2006, of Minatec, a $70,000 \mathrm{~m}^{2}$ research complex (including nine instrumental platforms) with the intention of it becoming the heart of regional - not to say national - nano-activity (Robinson, Rip \& Mangematin, 2007: 875-876). The main idea was to integrate scientific, industrial and educational activities on a new site (a 'campus') of nano-innovation. Again, this effort follows a classic pattern of public support for science and technology, i.e. the creation of innovation centres 'that bring together engineering and scientific disciplines to address fundamental research issues regarded as crucial to the next generation of technological systems' (Klein, 1996: 178 189). ${ }^{16}$

The CEA also intensified mobility from its Technology Department to its Basic Science Department, where higher management jobs were offered to applicationoriented people*. At the same time, managers from industrial firms were hired to run the Technology Department. No wonder, then, that researchers say they can 'read CEA real politics through appointment news' (RI2).

\subsection{Scientists' experiences of material, organizational and cultural boundaries}

Data collected at the CEA Grenoble show that the scientific convergence is real around objects (self-assembling molecules, fullerenes and nanotubes, quantum dots) and instruments (MBE systems, STM and AFM microscopes) typical of nanoscale research (Marcovich \& Shinn, 2010a). Some of those objects can definitely be considered as 'boundary objects', whose study is 'a key process in developing and maintaining coherence across intersecting social worlds' (Star \& Griesemer, 1989) $+{ }^{17}$ Data nonetheless also demonstrate that organizational and cultural distinctions are not (yet) erased in the project-based world of the physicists interviewed in the study. The local NST development instead acts for local researchers as a reminder of the persistence of many boundaries within the science and technology landscape they work in.

Some of those boundaries are very material ones, and sometimes very noticeable ones, even for the lay observer. Access to certain laboratories is often subject to strict formal procedures collaborators find tedious to follow. Those rules cannot be considered as neutral insofar as researchers look for fluidity and easy meeting procedures. ${ }^{18}$ Security rules are also sometimes obstructive, notably since they can make cooperation with some countries' nationals (e.g. Chinese, Iranians ...) difficult. Other security imperatives, applied to shared instruments, are not suited to all users, and some scientists say these prevent them constructing the experiments as they would like: 
To put my samples in an MBE [system], where there is an extremely high vacuum ... it's [considered] absolutely scandalous ... We make particles with a dirty chemical sauce, and we wash them roughly with ultrasounds... We can't put that in their [machine] ... In fact we could. but there are barriers, psychological barriers. That's a kind of prejudice. (R8)

Stories heard during the study show that the understanding of people's and objects' circulation in the local scientific networks wouldn't be complete without the account of the effects of those material and procedural obstacles. Nonetheless, interviews with local scientists demonstrate that such practical barriers seem less challenging for them than immaterial ones, as their nano-activities appear to make them (re)discover the thickness of cultural differenees between various professional communities. As D Vaughan's NASA example famously demonstrated, 'most science and technology is done in socially organized settings that can hardly be described as neutral', especially when they house an 'uncomfortable coexistence' of various 'cultural imperatives'. 19

Many physicists at the CEA Grenoble indeed evoke the cultural 'shocks' and 'shortcircuits' they experience - for better or for worse - as destabilizing events in their routines when prompted to work with 'differently wired' colleagues (as they picturesquely said). So, if NS/T is unquestionably associated with an interdisciplinary and intersectorial push, the working experiences it leads to make those physicists fully - and very concretely - aware of the variety of ways to make and think about science. ${ }^{20}$ They were very open when talking about those 'shocks':

I'm currently working on [an applied research laboratory's] instrument and ... They have different ways of working ... different ideas on good ways of working - a very managerial idea that is. There are managers and engineers, and technicians, and everyone stays in his box, everyone has his assignments. Here we are in a [basic] research laboratory: that's totally different ... We don't have the same audiences ... We ${ }^{\prime}$ re in an academic world, and they ${ }^{\prime} \mathrm{re}$ in an industrial onc. (L26)

When 1 left [the Technology Department] for my research laboratory, I discovered another occupation ... One's commitment is not the same, (R14)

Working in applied or basic research ... you don't have the same reasons to get up in the morning. (R16)

The temporality [of work organizations] is really not the same, and so cultures are different, but also the needs. So the shock has to happen. The shock is structural ... There is a permanent conflict ... a culture-clashing conflict. (L15)

Those clashes happen especially around scientific instruments shared, permanently or not, by various research communities. A spectacular case was observed when scientists from the basic research community (also microscope specialists) and others from the applied research community confronted their desires and practices when a new transmission electron microscope (TEM) was installed. A couple of days after its arrival, such concerns as 'who put his backpack on which workspace in front of it?' was a sensitive 
matter. More generally, it appeared that 'basic' physicists were especially committed to 'open' experimental devices, adapted to scientific tinkering and loose hierarchical structures. Their culture - and their professional identity - is based on the practices these kind of devices enable (on the culture of tinkering and its organizational grounds in these labs, see Jouvenet, 2007). This observation is cognate with the stress many science studies scholars have put on the link between material and non-material aspects of research cultures. ${ }^{21}$ In other words, 'know-how' (skills and competences) and 'know-that' (informations and representation) go together (Barnes, 2001: 21), and this entanglement explains why Grenoble physicists express great concerns about the material and organizational transformations they recently observed in their workspaces. Those transformations are seen as threats to the 'shared possession of a collective' (Barnes, 2001: 25), their scientific practices and collective identity. It also explains why the creation of Minatec appears as a cultural event, since it entails the visible, public enactment of new patterns so that "everyone can see" that everyone else has seen that things have changed', especially as 'anchoring practices' (i.e. 'those that enact constitutive rules that define fundamental social entities') are at stake (Swidler, 2001: 86-87). The negotiation of the respective 'rank and role' of science and technology communities is a matter of 'cultural values' and 'beliefs', as P Forman described it (Forman, 2007), but also inseparably of practices and the changes that happen within organizations.

\section{Boundary work and meaning in heterogeneous networks}

\section{I 'Regimes of production' and their boundaries in scientific communities}

Data collected among physicists in Grenoble show that cultural differences don 't dissolve in NS/T networks. It is therefore difficult to see the 'new organizational formats' of the local innovation policy as being tantamount to the creation of "a seamless web between science and economy' (Etzkowitz, 2005: 88). Following Grenoble physicists, one is instead incited to acknowledge the cultural 'thickness' of networks dynamics by accounting for how researchers experience and make sense of the cultural properties of their communities. The importance of cultural commitments appears at the very least to be because they influence individuals' inclination to engage (or not) in some networks and projects (cf. also Padgett \& Ansell, 1993; Padgett \& McLean, 2006). From this perspective, science and technology networks do not appear superconductive, nor scientists ' identities hyper-plastic, i.e. changing rapidly as individuals are enrolled in creditmaximizing (more resourceful) networks. On the contrary, my study shows how a kind of cultural resistance curbs the merging of communities, and limits the plasticity of individual profiles (see also Louvel, 2011, on the importance of laboratories' organizational cultures in Grenoble). The preferences CEA physicists express in their workspaces explain why some people are easier to match than others in local collaborative projects. In other words, the dynamics of interaction and exchange cannot be reduced to mere arithmetic, as networks-building is clearly influenced by cultural attachments. Which means that it is difficult to make full sense of interviews and observations made in 
Grenoble using the Actor Network Theory (in which institutional and cultural memberships interfere weakly in scientists' circulation and involvements) or the New Production of Knowledge model (Gibbons et al., 1994; Nowotny, Scott \& Gibbons, 2001), which tends to outdate the existence of stable groups sharing an identity, goals and skills (Shinn, 2005: 744) . $^{22}$

As the late D Forsythe also observed, 'conversations, meetings, and conflicts that make up the scientists' daily work life' play an important part in the construction of the collective identity - especially as they display statements about boundaries (Forsythe, 2001: $88 \mathrm{ff}$ ). For the physicists encountered during the study, it is the local boundary that scientists share with local engineers that causes them the biggest concerns and proves the hardest to erase, despite great efforts made by political actors. This boundary defines a major site of interaction between two 'communities of practice' (Wenger, 1998), physically near but very differently organized. Differences between those two 'communities' (an indigenous term) can usefully be characterized using Shinn's distinction between 'utilitarian' and 'disciplinary' regimes. ${ }^{23}$ Those 'knowledge production regimes' encompass different ways to select major scientific topics, to organize the trajectories of objects and persons, and to transmit knowledge (Shinn, 2006, 2008). Differences in the mode of selection of scientific topics, at least, were obvious for the interviewees. More often than not, reasons prompting basic physicists' collaborations with 'applied' physicists or engineers are indeed clearly more industry oriented than those they usually follow. In the labs, this feeling was conveyed through reference to technological and industrial deadlocks that caused applied physics teams to enrol scientists or technicians from the basic research department in their projects (see also Jouvenet, 2012). Some of these researchers, who worked in the synchrotron facility (ESRF), were for example instructed to participate in a big project on copper cables directed by the biggest local (and very industry-friendly) lab.

Interviews also confirm that 'utilitarian' and 'academic' communities are characterized through the role and position their members share - and defend - in the social world (Shinn \& Ragouet, 2005: 178). Shinn has expressed dissatisfaction with the way P Galison's 'trading zones' (Galison, 1997) are limited to technical and theoretical activities. The Grenoble data also prompt one to complete the 'trading zone' model in the way 'moral economies' (Thompson, 1971) complete economic exchange, ${ }^{24}$ for there is more to those interactions than technical dominance. In other words, they go beyond the composite set of claims, activities, and institutional structures that define and protect knowledge practices', since scientists 'work directly and through institutions to create, maintain, break down, and reformulate boundaries between knowledge tunits' (Klein, 1996: 1; emphasis added). Furthermore, the way individuals experience themselves as community members makes it necessary to tie the 'knowledge production regime' to collective identities (almost as absent from the 'regimes' model as from the 'trading zone' model, for that matter). ${ }^{25}$

From this perspective, the Grenoble science and technology hub functions as an "arena" 26 in which the collective identity associated with the disciplinary regime is negotiated through the boundary work members of its local community engage in when confronted with their 'utilitarian' colleagues. ${ }^{27}$ Regarding the Grenoble data, the 'regimes' model offers welcome compatibility with the classic interactionist framework. 
and Shinn's typology appears as a characterization of professional segmentation (Bucher \& Strauss, 1961; Freidson, 2001) in the scientific world.

\subsection{Asymmetry in the process: from culture to politics}

The CEA Grenoble shows clearly the integrative organizational dynamics at work on many NS/T sites. Enabled by experimental objects, through scientific instrumentation, it is also a product of innovation ideologies and policy, embodied in specific organizational devices. This policy nevertheless faces serious limits on the fieldwork, due to cultural features constituting the various research communities. Interviews conducted with 'basic' physicists show that the gap between expected innovative mixings (or "hybridizations") and concrete difficulties is probably widest when they have to build partnerships with local engineers. They may share the same disciplinary background (condensed matter or solid-state physics), but their scientific activities are conducted under distinct regimes, with different work philosophies. The study's interviews indeed show that each of these local communities has its own "professional philosophy' (Hughes, 1996), which fosters a collective identity and shapes individuals' commitment to their work.

Actually, data collected in the laboratories show that scientists in the 'disciplinary" community not only often find it difficult to work nearer the 'utilitarian' community, most of them also see this interaction as competitive - and threatening. This threat has an obvious symbolic dimension, for 'basic [or 'blue sky'] physicists' fear for the 'purity' of their work - and therefore the hierarchical status of their professional segment (Abbott, 1981). But it is also very practical, since they feel engaged in a competition for credibility, i.e. resources and legitimacy (Latour \& Woolgar, 1979), in an arena where two segments of their profession compete for political favours (just as whole professions compete to gain commercial favours in Abbott, 1988). ${ }^{28}$ And the overall impression is, first, that this competition will have a striking impact on their future activities (and professional destinies) and, second, that this competition is somewhat flawed.

This concern stems from awareness of the proximity between industrial, political and applied research actors peculiar to the Grenoble area (Grossetti, 1995; Pestre, 1990). Private-sector local protagonists (notably from the electronic industry: IBM, Motorola. Freescale and STMicroelectronics are among the main stakeholders) have made huge investments there, and the CEA laboratories have always been considered among the best assets to attract such moves. Grenoble is indeed a much-cited example of the concrete form the 'innovation policy' has to take in France. ${ }^{29}$ Applied research laboratories are very important and powerful actors, and their members' proximity with their colleagues from industry (the mobility between the two is high) is clearly visible in the way they organize and manage research activities. Public laboratories' cleanrooms and industrial ones run $24 / 24 \mathrm{~h}$ in 8 -hour shifts, often sharing the same instruments, and prototypes are moved from one to the other (Hubert, 2007). Their scientific strategy is also defined with close attention to industrial roadmaps. This proximity is resented even in some applied public laboratories, where there are scientists and engineers who consider roadmaps like the ITRS destructive of exploratory research. ${ }^{30}$ 
From the 'basic' physicists' side, the resources that applied research laboratories are able to gain for cooperative purposes prove difficult to mobilize outside the industrial framework and agenda. This is why the priority given to 'utilitarians' by political actors is seen as such a threat for their professional culture and identity by the physicists in the 'disciplinary' community - especially as the need for 'soft money' Iures their projects towards applied science, which are easier to 'sell' to funding agencies (Barrier, 2011; Jouvenet, 2011). ${ }^{31}$ The 'doability' of their work is palpably impacted, since it changes the 'alignment' of the 'levels of organization' of experiment, laboratory and social worlds, to use J Fujimura's famous lexicon (Fujimura, 1987).32

When money comes through [applied research labs] and they distribute it in dribs and drabs ... when they hold the purse strings, obviously, they give money to fundamental [science] activities that seem nearer to their needs to them. And that push fundamental [science] researehers to work [like them]. (R20)

We are pushed to share our working spaces with ... bulldozers. We have to avoid being eaten. (R14)

We fear we will be foreed to work on their [electronic] components ... This would lead to a collective suicide. (R8)

Being able to attract more money than their 'basic science' colleagues, "applied science' physicists are prone to exert a significant control over the scientific work planned in common projects - or on instruments tied to those (asymmetric) partnerships. A physicist, for example, told me how he once had to fight to keep a molecular beam epitaxy system he needed for his experiments switched on, ${ }^{33}$ because his 'applied' partners simply wanted to switch it off as soon their European PCRD working package they had bought it for was done (L15).

More generally, the asymmetry in the local NS/T integrative dynamic was for interviewed basic physicists a cause of Freidsonian 'deprofessionalization' process (Freidson, 2001), as they see their academic 'intellectual and professional autonomy' (Whitley, 1984) being progressively undermined by management and market logics. This feeling gives its political meaning to the 'culture clashes' experienced at the lab level (sometimes even during scientific experiments, as I have observed).

Certainly, 'rich science policy constituted a set of necessary conditions for the gigantic output that we witness today in [NS/T, where] money speaks with a loud voice' (Marcovich \& Shinn, 2010a: 234). But it must also be noted that its spokespersons are not equally represented among local research communities. Data collected in Grenoble indeed confirm the analytical importance of the "attention to the ways in which collaborative need is defined and how it evolves', to the 'social construction of collaborative necessity' (Shrum, Genuth \& Chompalov, 2007: 203-206) - and to its level of acceptance among scientists. In other words, taking scientists' experiences into account pleads for the political and historical contextualization of a negotiation arena between communities. As cursory they are, the insights I have given here about this larger picture also enable us to characterize regimes' coexistence and their 'trading zone' using Collins, 
Evans \& Gorman's (2007) diagram: data collected in Grenoble suggest that the workspace shared by basic and applied physics researchers is nearer to the "enforced trading zone (high coercion, high heterogeneity)' than to other ideal-types. ${ }^{34}$

\subsection{Boundary work as (professional) rhetoric: shifts in collective legitimacy}

T Gieryn and S Shapin showed how collective 'repertoires' enable the rhetorical work legitimating the identity and value of a scientific activity or profession (Gieryn, 1983: 783; Shapin, 2010: 142-181). Though on a more micro-sociological level, rhetorical work appears here also as a dimension of boundary work, meant to negotiate a professional role and a collective identity in relation to local power networks patterns. And the great value publicly given to the industrial/economic rationality - "the dominance of the economic culture' over the 'social contract for science' (Elzinga, 2005: 549) - makes it an inevitable commonplace for the disciplinary regime members, an unavoidable environmental resource to exploit in their identity construction. In other words, they are seized by a (utility-oriented) commensuration process (Espeland \& Stevens, 1998), ${ }^{35}$ and it encourages them to adapt the old song of 'the practical benefits of pure science' (Gieryn, 1983) to their local audience. Strikingly alive in the Grenoble area (at least during the study), the 'disciplinary/utilitarian' dichotomy is mobilized and produced (in a word, negotiated) in a professional rhetoric through which organizational and cultural features of basic scientists are presented as public goods politicians have to protect (see also Jouvenet, 2007, 2009). It is a way for them to state 'what's special about basic research' (Calvert, 2006).

This local version of an 'interpretative wall' aimed to protect their professional autonomy (Gieryn, 1983: 782-783; 1999: 17) is a moving one: the global empowerment of 'utilitarians' in recent years explains the shift of local voices engaged in basic science towards the promotion of the economic efficiency of the basic labs' free creativity and distributed organization (away, then, from a 'pure' research ideal - the pursuit of knowledge for its own sake). They simply consider it now the more efficient way to present their expertise (a way of doing science) as a valuable good for the whole society. In this sense, it is a 'jurisdictional claim' (Abbott, 1988) in the competition for credit between the various communities composing the local ecosystem. As mentioned above, the creation of new organizational devices (Minalogic) and the building of new research sites (Minatec) were key events in this ecosystem - events which marked the evolution of the local 'science/society contract' (Elzinga, 1997; Slaughter \& Rhoades, 2005; Taylor, 1998). ${ }^{36}$

I have to admit the official communication on Minatec was excellent ... maybe too excellent. for that matter. When I'm presented to people I don't know, now they always tell me: "oh, you are a physicist? ... then you must work at Minatec, don't you?' (R20)

As Gieryn (1983), following Mulkay (1976), stated, the choice a scientific community makes of a 'repertoire for public description of science in its boundary work is 
determined by the moment and nature of the challenge posed to their authority'. Here, basic physicists' collective rhetoric was adapted to and directed towards both local politics and other scientists - who are their competitors but also, more and more, their partners in the local 'struggle for credibility' (Gieryn, 1999). This sociological understanding accounts for the ambivalence basic physicists expressed during interviews: in a way, their discursive flexibility is an enabling trick ('the reed bends but does not break', as La Fontaine's famous fable says); yet it has also the bitter taste of failure, as they are forced to play a demanding role in a game they resent.

It should be clear by now that here rhetoric is not a tool for individual performances by credit capitalists, a strength display (as it is often described in science studies - and notably in the Actor Network Theory), ${ }^{37}$ but instead a conciliation offer between groups sharing the same social ecology. It may therefore be fruitful to come back to the concept of rhetorical work as a practical action constituting groups through the (historically and locally) apt expression of 'commonplaces' (Goyet, 1996). ${ }^{38}$ The sociological study of the Grenoble 'nano boom' has shown how it would be possible to study forms and modes of distribution of this rhetorical work among various actors (Delemarle, 2007; Hubert, Jouvenet \& Vinck, 2013; Vinck, Gallice et al., 2007; Vinck. Hubert et al., 2006).

\section{Conclusion: Science policy and actors, seen from the lab}

Interviews and observations conducted in Grenoble's (nano) laboratories by the author and his colleagues show how difficult it is to separate organizational, material and cultural dimensions when trying to understand researchers' moves in local networks (Hubert, 2007, 2011: Jouvenet, 2007, 2009; Vinck \& Zarama, 2007; Zarama \& Vinck, 2011). Moreover, data produced by the sociologists made it clear that this multidimensionality was not an exclusive feature of their perspective, since physicists we met were obviously aware of it. Instead our observations encourage acknowledgement that the laboratory is not just a printing machine (Latour, 1989), but also a forum where professional concerns are discussed, during scientific events, in the labs' corridors or at coffee breaks, fuelling collegial sociability. In these discussions, their discourses indeed often link the scientific practices, organizational patterns and political choices going on in various workplaces. Traces of this indigenous reflexivity are perhaps too rare in science studies - even in socalled laboratory studies.

It is possible, however, that this awareness is especially high in the Grenoble context, which traditionally offers many occasions to appreciate the intermingling of scientific, technological and political realms - at the very least because the well-known stories of the city's key figures highlight these links, and because its economic and demographic dependence on techno-scientific innovation is often debated in public and media discourses. This contextual sensitivity may be one of the limits of this case study. The years during which the study was conducted have also undoubtedly expanded concerns about the embeddedness of scientists in the urban and socioeconomic local life for Grenoblois who were able (as scientists or laymen) to witness the concrete forms the nano bet was beginning to produce - the industrially oriented Minatec building and its 'transfer' facilities, notably. 
Following the main concern of basic physicists, this article has stressed the political dimension of research communities' cultures. ${ }^{39}$ It has shown that they encompass what A Elzinga described (though for more macro levels) as 'policy cultures', aiming to 'steer science and technology in a particular direction', as they shape those communities' involvements in a local version of the "competition for resources and influence' (Elzinga, 2005: 'The question is who is on top?', as Elzinga also wrote).

The attention paid by laboratory members to the political dimension of ecological interactions in the scientific and technological landscape offers a striking contrast with two versions of the laboratory scientist often displayed in science studies. First, the individuals encountered in Grenoble's laboratories differ clearly from the 'Ivory Tower' ideal-type, defined less by concentration on scientific tasks than by a refusal to accord any importance to the link between lay and political networks and these tasks. The wish of the physicists interviewed to be considered as a legitimate political voice in the local orchestration of the innovation policy hardly resembles the chemists depicted in one of the first sociologies of a scientific profession, characterized by their sociological 'nearsightedness' (Strauss \& Rainwater, 1962: 159-160). ${ }^{40}$ Mertonian sociology of science also tended to erase the embeddedness of academic communities within political networks by stressing their autonomy. ${ }^{41}$ The case presented here instead offers an illustration that 'the categories of the scientist and citizen cannot remain distinct and exclusive' (Ravetz, 2005: 484) - or at least that they can't always be kept separate. This article has also shown that the articulation of the scientific and the political is a cultural feature of local communities. Local basic physicists, for example, share a discourse and a rhetoric that allow them to construct their value as a community working in the public interest. They present their community as an essential component of local political struggles. The importance of community membership for local physicists contrasts again with the "science capitalist' ideal-type. This ideal-type is often associated with a sociological analysis that focuses on individual scientists' moves and credits maximizing strategies (like the Actor Network Theory). Data collected in Grenoble suggests that this ideal-type is not so much irrelevant as incomplete, for basic physicists expressed concerns not only about their personal credit but also about the way to organize and combine various research communities in the public interest. Their involvement in discussions about (science and technology) professional cosmopolitanism and its social conditions prompts us to define the political sense of the scientist not only in a Hobbesian way (through personal power claims) (2) $^{42}$ butso in an Aristotelian architectonic way ${ }^{43}$ (see also Jouvenet, 2012: 58-60).

Marcel Mauss wrote (after a case discussed in Aristotle's writings) that 'three days after its storming, a part of the city [of Babylon] was not aware of it', because of its 'loose cohesion'. This kind of society can 'be amputated, mistreated, even decapitated; they are sensitive neither to their frontiers, nor to their internal organization ... They are neither vertebrate, nor strongly conscious; they are not touched by the very loss of their political features' (Mauss, 1969: 582). The case discussed in the present article depicts the opposite situation: physicists clearly expressed their desire to protect the cultural features of their professional community - and showed their ability to construct them as public goods, essential to the public interest (economic growth). 


\section{Acknowledgements}

I would like to thank Jérôme Lamy, Amaud Saint-Martin and Terry Shinn, who produced helpful commentaries on a first draft of this article, I am also grateful to this journal's anonymous referees. whose remarks were also highly constructive.

\section{Funding}

A part of the study exploited in this article was made in the LODYSENANO framework, a project funded by the Agence Nationale de la Recherche (no. ANR-06-BLAN-0341).

\section{Notes}

I Activities in NS/T essentially encompass the building and characterization of surfaces or objects of nanometric seale (one of the dimensions of the considered object is smaller than 100 nanometers).

2 For a brief overview of the 'nanotechnology funding boom' (and its impact on publication patterns), see Shapira \& Wang (2010). 'The measure of the degree of growth in the field of nanoseale research both in numbers of practitioners and the quantity of research production can be seen in the publications, which increased from fewer than 30.000 between 1988 and 2000 to over 100,000 between 2001 and 2009' (Marcovich \& Shinn, 2011: 591).

3 By 'integrative process' I mean a process that conflates entities (e.g. research units or communities) previously separated.

4 The dominant sociological perspectives on NS/T focus on the "public reception' of seience, as the careful framing of dialogues between laymen and scientists is considered a specific feature of NS/T dynamies (and is well funded).

5 The problem here is therefore not to draw a line between scientists and the rest of the social world, as in Gieryn's canonical work (Gieryn, 1983), but rather within the scientists" professional world. As Gieryn wrote himself, "the utility of boundary-work is not limited to demarcations of science from non-science. The same rhetorical style is no doubt useful for ideological demarcations of disciplines, specialties or theoretical orientations within science' In any case, the examination of this demarcation has to be conceived as a "practical problem". empirically investigated, and 'not just an analytical problem' (Gieryn, 1983: 791-792).

6 "Characteristic [of science studies literature on NS/T] is that even the most insightful critical examinations of nanotechnology ... elide completely the distinction between science and technology and use the terms interchangeably (Forman, 2007: 80, n. 53).

7 Observations and interviews conducted in the labs have indeed shown that the research communities were differentiated by their members as having two different "cultures', and the following analysis was elaborated on this perspective. The term is famous for its elusiveness (Cuche, 1996; Spillman, 2007), and it may be convenient, then, to frame its use. By using the game metaphor ('different games, with different rules and meaning'), I want to stress the set of rules and institutions which makes a social form of life (as it is conceptualized in the "second ' L Wittgenstein philosophy, as both a tool and a milieu. Cf. Winch, 1990[1958]: notably 8486 , on the very example of a form of activity shared by 'fellow-scientists'). Historians demonstrated how this concept of culture can foster an analysis of historical processes of network construction by negotiation between groups (Padgett \& Ansell, 1993: Padgett \& McLean, 2006; see also Emirbayer \& Goodwin, 1994), while insisting on the inseparability of its diverse dimensions ('routine, cognitively supported practices, and values and affects called upon to shape or reinforee preferences', McLean, 2007:39). "Culture is both a world we live in, and a tool we use' (McLean, 2007: xii), and I also consider it here as a repertoire for actions, interactions and strategies (Swidler, 1986, 2001). 'Culture' is a term that enabled 
STS scholars to define collective identities by identifying shared meanings and practices in the whole academic world (Shapin, 2010), in various countries (Fourcade, 2009; Houdart. 2008) and disciplines (Dahan, 2005; Forsythe, 2001; Knorr Cetina, 1999; Traweek, 1988) or in specific organizations (Vaughan, 1996: a book influenced both by Chicago School sociology and J Padgett's cultural history, as stated in its acknowledgements) ... In particular, it has been essential to the second wave of ethnographic studies of science in the STS field" that was broadly interested in issues of power negotiation (Hess in Forsythe, 2001: xix). $\Lambda \mathrm{s}$ it will appear, the Grenoble basic physicists' culture discussed here yokes organizational features, disciplinary practices, identity repertoires and a collective orientation - all tuning their involvement in the local struggle for professional power.

8 The Grenoble situation is not representative of all NS/T activities in France. Research threads and actors are for instance organized very differently in the Institut de Nanoscience de Paris. where the integrative efforts evoked here are almost invisible. Nevertheless, the Grenoble case has been promoted as a model in recent French innovation policy: the Nano-Innov 'integration centre' that opened in 2011 in Saclay is for example explicitly linked to that in Grenoble (and could offer a close case to study).

9 This disciplinary homogeneity is an obvious limit of the study because it leaves no room for weighing the influence of the peculiar identity and history of the discipline, nationally or locally, on the mobilization of physicists in Grenoble (on this history and identity, see Pestre, 1990, 1992[1984]). A comparison with biologists or chemists, not possible with available data, would be essential for that.

10 For that I want to thank here the colleagues who worked with me in the LODYSENANO project: D Vinck, M Hubert and G Zarama. I am also grateful to the CEA representatives who supported the study and to the physicists who agreed not only to be interviewed but to show me how their experiments worked (or should work).

II Mainstream media regularly offer insights on NS/T spectacular dynamics, making puns about 'nano's big future' (Kahn, 2006) or the 'nanobubble' (Surowiecki, 2004) pervasive. Stories exploit the impressive range of (very) optimistic or (very) pessimistic scenarios scientists, politicians or journalists associate with the knowledge produced and the technological breakthroughs made at the nanoscale (where manipulation of matter is now happening one atom at a time).

12 Interviewees are identified here with a letter linked to their status (D/PhD student, R/ researcher, $\mathrm{L} / \mathrm{lab}$ manager, and $\mathrm{M}$ /higher management), combined with an interview number.

13 Marcovich \& Shinn (2010b: 632) also concluded from their interviews with award-winning NS/T scientists that 'despite the pronounced circulation and synergy of practitioners across many disciplines and involving many different kinds of projects, Feynman laureates nevertheless continue to identify with their home discipline:

14 Cited in Les Défis du CEA (September 2005: 20). On this leading figure in the local political and scientific world, see Delemarle (2007). The idea that science adventurers are nowadays easier to find at the border between disciplines, rather than at their core, is also widespread in science worlds (see e.g. Crease, 2008).

15 This project-based - and project-funded-logic appears as a good example of the "new disciplinarity 'defined in Marcovich \& Shinn (2011).

16 This policy has already been adopted for biotechnology (Klein. 1996: 180, 185), and it has given scholars a good reason to compare public policy and its impact on research collaborations in those two domains (Bozeman, Larédo \& Mangematin, 2007).

17 Industrial and scientific actors are for instance sharing a curiosity for carbon nanotubes, which present a new scene to explore still obscure phenomena and display outstanding physical properties likely to fulfil important technological hopes. 
18 The physical materiality of those limits sometimes verges on comedy when one is also confronted with the overall stress placed by managers on the openness and fluidity of local scientific networks. Using a picture of a 'Physics Crossroad' road sign (as seen on the approach to some laboratories included in the study) to illustrate this official discourse in various communications, 1 discovered later that it also produced a telling image of the border between CEA and CNRS territories on the local "scientific polygon" - as the material border stood in the background, complete with fences and barbed wire.

19 Affirming 'the work group's definition of the situation, informing its sense-making in common directions', these cultural beliefs are 'part of the worldview that work group participants brought to decision making, providing taken-for-granted sets of invisible rules about how to act in the situation that they faced' (Vaughan, 1996: 396, 402).

20 In a mirror observation. Hemlin \& Rasmussen (2006: 190-193) have also noted that the instability of scientists' professional space prompts them to question more easily 'their own values and practices:

21 A reeent STS textbook defines culture as "the "glue" of shared ideas, manners, and things that unite a community ... It includes material and non-material aspects from artifacts and things to symbols, attitudes, beliefs, values, norms and social organization' (Bauchspies, Croissant \& Restivo, 2006: 122).

22 Data collected in Grenoble therefore concur with Shinn's critique of 'anti-differentiationist' modes of analysis, and his claim that a third analytical approach is needed, enabling the balance of network fluidity and boundary effects in the understanding of the sociological drives of science. Shinn states that science and technology studies are for now structured by an opposition between 'differentiationist' and 'anti-differentiationist' trends. Recall that the former tend to emphasize the segmentation of the science and technology field by organizational, institutional and disciplinary demarcations; on the contrary, followers of the latter stress openness and fluidity of seientific activities (see Shinn, 2005: 743-744: Shinn \& Ragouet, 2005).

23 Shinn explains that, since the 17th century, the production of scientific and technological knowledge has taken five 'intellectual and institutional forms' associated with distinct professional cultures, namely: the 'disciplinary", 'utilitarian', 'transitory', 'transverse' and 'regulatory" regimes.

24 In his famous study, EP Thompson showed how cconomic relations are embedded in a system of norms and obligations that define class agency. This move gave a new importance to actors" experiences and subjectivities, and has been adapted to various fields by multiple authors (Fassin, 2009). In STS, moral economies have been presented as a normative culture linking science practices and ideals (Daston, 1995; MacCray, 2000). This import emphasizes the mark collective institutions make on individual profiles in scientific communities, "beyond the calculus of self-interest, strategically deployed to the ends of discipline-or career-building". It stresses 'how intellectual work is saturated with moral, emotional, and aesthetic elements at at collective, not just a biographical, level ${ }^{+}$(Daston, 1995: 24).

25 Shinn's transversalist model oscillates between the macro and the micro levels, but eludes collective entities by focusing on instruments and individuals (Lamy \& Saint-Martin, 2011: $384-386$ ).

26 Following A Strauss, Clarke \& Star (2008) present sites of 'boundary work' in science networks as "arenas": "An arena is composed of multiple worlds organized ecologically around issues of mutual concern and commitment to action:. In those arenas, boundary objects "are used not only as translation devices but also as resources for the formation and expression of professional identities' (Clarke \& Star, 2008: 113, 126). Wenger (1998: 291, n. 2) also compares the link between 'communities of practice' to that between Strauss's 'social 
worlds'. Another similarity is the stress put on the actor's 'experience of meaning' and identity construction.

27 It has been similarly observed that working "between basic research and the treatment of patients' on 'biomedical platforms' creates new standards and tools, but also has an influence on collective identities (Keating \& Cambrosio, 2003: 38-41).

28 The ecological theory of A Abbott provides a resourceful framework to explore the ways negotiations happen between professional groups. His model of 'linked ecologies' is morcover not specific to the system of professions: 'the university system' is for example a space where groups less 'well defined and stable' than professions 'fight for control of on the one hand material resources for research and instruction and on the other hand areas of knowledge and intellectual endeavor' (Abbott, 2005: 246, 249-251).

29 'The strong ties between public research and industry are here an obvious fact that 1 wish to see gain ground in other areas of our country", said for example the then-Président de la République Nicolas Sarkozy when he visited Grenoble (cited in Le Journal du CEA Grenoble 85: 2). On innovation policy in France, see Larédo \& Mustar (2001) and Mustar \& Laredo (2002). The extent of the privilege now given to applied or industrial research by public policies is much debated in STS (see Nowotny et al., 2005 for example).

30 The ITRS is 'an innovation killer', says a researcher in an applied physics laboratory, whereas his manager loudly fears that Grenoble labs may be 'trapped by the roadmap effect' (interviews conducted by $D$ Vinck).

31 Rosental (2007) shows how looking for partners (and funding) can be an important source for the transformation of scientific practices (and rhetoric).

32 Frickel \& Moore (2006) present various analyses on the material sources and cultural impact of asymmetric relations between research communities in biotechnology (see especially chapters by Kleinman \& Vallas, Owen-Smith \& Wolf).

33 On this importance of the MBE system for nanoscale research, see MacCray (2007).

34 -A more general model of trading zones can be developed by considering two dimensions along which trading zones can vary. One dimension is the extent to which power is used to enforce trade - this is the collaboration-coercion axis. The other dimension is the extent to which trade leads to a homogeneous new culture - this is the homogeneity-heterogeneity axis' (Collins. Evans \& Gorman, 2007: 658, and 665 for the diagram). Still, 'trading zones' are not necessarily irenic: Galison (2003: 679-680) notes that sometimes a group may have more power than another to impose their language or technique.

35 "Commensuration changes the terms of what can be talked about, how we value, and how we treat what we value. It is symbolic, inherently interpretive, deeply political' (Espeland \& Stevens, 1998: 315). Basic science workers in Grenoble are especially sensitive about the fact that presuppositions for commensuration often reflect assumptions about commodification that are inherently political and asymmetrical' and that 'efforts to translate incommensurable values into commensurated value not only can distort the character of people's investments but can repudiate identities that are closely linked to incommensurable values'. The Grenoble data confirm Espeland \& Stevens's hypotheses that the most frequent and most durable claims about incommensurability occur at the borderlands between institutional spheres, where different modes of valuing overlap and conflict ... and where proponents of a particular mode are entrepreneurial' (Espeland \& Stevens. 1998: 326, 332; emphasis added). Frickel \& Moore (2006) offer other confirmations for biotechnology.

36 Kevles (1995[1971]), on the making of the US National Science Foundation, and Galison (1996: 7), on the Superconducting Super Collider debate in the US, have also shown how this kind of project induced boundary works between distinet physics communities. 
37 Abbott (2004: 92) has also noted the simplistic use of the term in contemporary sociology ("we often use "rhetoric" as a negative word, to label tricks of language or argument. We think of rhetoric as false or at least deceptive'), contrasting with the ancient idea of "a good thing, both positive and creative'.

38 F Goyet (1996: 250, 676, 715) offers a history of classic authors' conceptions of commonplaces (lieux communs), revealing their original inclusion (as rhetorical tools) in clever political moves that also reinforee the community bonds. In this perspective, "commonplaces' are mobilized to define a type of link to public interest, and the stress is put on the federation rather than on the secession. It is a way to gain authority while reconciling distinct parties, rather than a way to crush an opponent.

39 This political dimension explains why the analysis of 'professional philosophies' is tantamount to "the study of politics", in Chicago School sociology (Hughes, 1996: 104).

40 This indifference has to be related to the relative harmony sociologists found in this confident community, described as free of internal political and professional struggles. However, the final pages of the book mention new 'cleavages' appearing in universities where 'some faculty have been hired who are specifically interested in applied science' (Strauss \& Rainwater, 1962: 213,221).

41 Actually, Merton's effort was 'to establish that science was inherently a democratic system that had been perverted by polities', notably in Nazi Germany (Moore, 2005: 553).

42 Hobbes's influence on Actor Network Theory is made explicit in Callon \& Latour (1981).

43 At the beginning of the Nicomachean Ethics, Aristotle defines politics as an architectonic activity, as it gives other activities their place and meaning in the city, 'relative to their significance and their function in the whole' (Descombes, 2008: 41: my translation).

\section{References}

Abbott A (1981) Status and status strain in the professions. American Joumal of Sociology 86(4): $819-835$.

Abbott A (1988) The System of Professions. Chicago, IL: University of Chicago Press.

Abbott A (2004) Methods of Discovery. Heuristics for the social seiences. New York, NY/London; Norton \& Company.

Abbott A (2005) Linked ccologies: States and universitics as environments for professions. Sociological Theory 23(3): $245-274$.

Barnes B (2001) Practice as collective action. In: Schatzki T, Knorr Cetina K, et al. (eds) The Practice Turn in Contemporary Theory. London/New York, NY: Routledge, 17-28.

Barrier J (2011) La science en projets: Financements sur projet, autonomie professionnelle et transformations du travail des chercheurs académiques. Sociologie du Travail 53(4): 515-536.

Barth F (1969) Ethnic Groups and Botundaries: The social organization of culture difference. Boston, MA: Little, Brown \& Company.

Bauchspies W. Croissant JL, Restivo S (2006) Science, Technology; and Society: A sociological approach. Oxford: Blackwell.

Baus D (2009) Cultural exchange in a heterogeneous research field: Approaching scientific culture with anthropological thought. Spontaneous Generations: A journal for the history and philosophy of science $3(1)$ : $95-104$.

Bensaude-Vincent B (2004) Se Libérer de la Matière? Paris: Editions de l'INRA.

Bozeman B, Larédo P, Mangematin V (2007) Understanding the emergence and deployment of 'nano' S\&T. Research Policy 36(6): 807-812.

Bucher R. Strauss A (1961) Professions in process. American Journal of Sociology 66(4): 325-334. 
Callon M. Latour B (1981) Unserewing the Big Leviathan; or How actors macrostructure reality, and how sociologists help them to do so? In: Knorr Cetina K. Cicourel A (eds) Advances in Social Theory and Methodology. London: Routledge \& Kegan, 277-303.

Calvert J (2006) What's special about basic research? Science, Techology and Human Values 31(2): 199-220.

Clarke AE, Star SL (2008) The social worlds framework: A theory/methods package. In: Hackett EJ, Amsterdamska O, Lynch M, et al. (eds) The Handbook of Science and Technology Studies. Cambridge, MA: MIT Press, 113-137.

Collett JP (2003) The history of electronics: From vacuum tubes to transistors. In: Krige J. Pestre D (eds) Companion to Science in the Twentieth Century. London'New York, NY: Routledge, 253-274.

Collins H, Evans R, Gorman M (2007) Trading zones and interactional expertise. Studies in History and Philosophy of Science 38(4): 657-666.

Crease RP (2008) Life at the frontier. Physics World 21(10): 45-48.

Cuche D (1996) La Notion de Culture dans les Sciences Sociales. Paris: La Découverte.

Dahan A (2005) Axiomatiser, modéliser, calculer: Les mathématiques, instrument universel et polymorphe d'action. In: Dahan A, Pestre D (eds) Les Sciences pour la Guerre, 1940-1960. Paris: Editions de l'Ecole des Hautes Etudes en Seiences Sociales, 49-81.

Daston L (1995) The moral economy of seience. Osiris 10(1):2-24.

Delemarle A (2007) Les Leviers de l'Action de l'Entrepreneur Institutionnel: Le cas des micro et nanotechnologies et du póle de Grenoble. Thése de doctorat en sciences de gestion, Ecole Nationale des Ponts et Chaussées.

Descombes V (2008) Philosophie du. Jugement Politique. Paris: Points Seuil.

Doing P (2009) Velvet Revolution at the Synchrotron: Biology: physics, and change in science. Cambridge, MA: MIT Press.

Elzinga A (1997) The science-society contract in historical transformation: With special reference to "epistemic drift". Social Science Information 36(3): 411-445.

Elzinga A (2005) Science policy, Development of. In: Restivo S (ed.) Science, Technology, and Society: An encyclopedia. New York, NY: Oxford University Press, 543-550.

Emirbayer M, Goodwin J (1994) Network analysis, culture, and the problem of agency. American Journal of Sociology 99(6): 1411-1454.

Espeland W, Stevens ML (1998) Commensuration as a social process. Annual Review of Sociology 24: $313-343$.

Etzkowitz H (2005) The Economy and Science. In: Restivo S (ed.) Science, Technology, and Society: An encyclopedia. New York, NY: Oxford University Press, 87-93.

Fassin D (2009) Les économies morales revisitées. Annales HSS 6: 1237-1266.

Forman P (2007) The primacy of science in modernity, of technology in postmodernity, and of ideology in the history of technology. History and Technology 23(1-2): 1-152.

Fourcade M (2009) Economists and Societies: Discipline and profession in the United States, Britain \& France, 1890 s to 1990 s. Princeton, NJ/Oxford: Princeton University Press.

Forsythe DE (2001) Studying Those Who Study Us. An anthropologist in the world of artificial intelligence. Stanford, CA: Stanford University Press.

Freidson E (2001) Professionalism, the Third Logic. Chicago, IL/London: University of Chicago Press.

Frickel S, Moore K (eds) (2006) The New Political Sociology of Science. Institutions, networks, and power. Madison, WI: University of Wisconsin Press.

Fujimura JH (1987) Constructing 'do-able' problems in cancer research: Articulating alignment. Social Studies of Science 17(2): 247-293. 
Galison P (1996) Introduction: The context of disunity. In: Galison P, Stump D (eds) The Disunity of Science: Boundaries, contexts, and power. Stanford, CA: Stanford University Press, 1-33.

Galison P (1997) Image and Logic. A material culture of microphysics. Chicago, IL: University of Chicago Press.

Galison P (2003) Material culture, theoretical culture and delocalization. In: Krige J. Pestre D (eds) Companion to Science in the Twentieth Century. London/New York. NY: Routledge, $669-682$.

Gibbons M, Limoges C, Nowotny H, et al. (1994) The New Production of Knowledge: The dynamics of science and research in contemporary society: London: Sage Publications.

Gieryn TF (1983) Boundary-work and the demarcation of science from non-science: Strains and interests in professional ideologies of scientists. American Sociological Review 48(6): 781-795.

Gieryn TF (1999) Cultural Boundaries of Science: Credibility on the line. Chicago, IL: University of Chicago Press.

Glaeser A (2000) Divided in Unity: Identity, Germany and the Berlin police. Chicago, IL: University of Chicago Press.

Goyet $\mathrm{F}$ (1996) Le Sublime du 'Lieu Commun': L'Tnvention rhétorique dans l'Antiquité et à la Renaissance, Paris: Honoré Champion.

Grossetti M (1995) Science, Industrie et Territoire. Toulouse: Presses Universitaires du Mirail.

Hemlin S, Rasmussen SB (2006) The shift in academic quality control. Science, Technology \& Human Values 31(2): 173-198.

Hessenbruch A (2004) Nanotechnology and the negotiation of novelty, In: Baird D, Nordmann A. Schummer J (eds) Discovering the Nanoscale. Amsterdam: IOS Press, 135-141.

Hoddeson L (2003) Solid state science. In: Krige J, Pestre D (eds) Companion to Science in the Twentieth Century. London/New York, NY: Routledge. 585-598.

Houdart S (2008) La Cour des Miracles, Ethologie d'un faboratoire japonais. Paris: Editions du CNRS.

Hubert M (2007) Hybridations instrumentales et identitaires dans la recherche sur les nanotechnologies. Revue d'Anthropologie des Connaissances 1(2): 243-266.

Hubert M (2011) Le róle des dynamiques d'organisation dans les sciences: Le cas des plateformes de caractérisation en nanosciences. Terrains \& Travaux 18: 175-192.

Ilubert M, Jouvenet M, Vinck D (2013) Politique 'de l'innovation' et transformations des mondes scientifiques. Le pari des nanosciences et nanotechnologies à Grenoble. In: Aust J. Crespy C (eds) Les Mutations des Politiques de Recherche: Entre état, marché et professions. Paris: Editions des Archives Contemporaines (forthcoming).

Hughes E (1996) Le Regard Sociologique. Paris: Editions de l'Ecole des Hautes Etudes en Sciences Sociales.

Jouvenet M (2007) La culture du 'bricolage' instrumental et l'organisation du travail scientifique: Enquête dans un centre de recherehes en nanosciences. Revue d'Anthropologie des Connaissances I(2): $189-219$.

Jouvenet M (2009) Le 'nanomonde' vu de l'intérieur. Le travail scientifique, ses évolutions et ses représentations dans le laboratoire. In: Appay B, Jefferys S (eds) Restructurations, Précarisation et Valeurs. Toulouse: Octarès, 193-205.

Jouvenet M (2011) Profession scientifique et instruments politiques: L'impact du finaneement 'sur projet' dans des laboratoires de nanosciences. Sociologie du Travail 53(2): $234-252$.

Jouvenet M (2012) Nanosciences et nanotechnologies: Une coopération modéle? Expériences et sens politique des scientifiques. Terrain $58: 44-63$.

Kahn J (2006) Nano's big future. National Geographic 209(6): 98-119. 
Keating P. Cambrosio A (2003) Biomedical Plafforms; Realigning the normal and the pathological in late-twentieth-century medicine, Cambridge, MA/London: MIT Press.

Kevles DJ (1995[1971]) The Physicists: The history of a scientific community in modern America. Cambridge, MA/London: Harvard University Press.

Klein JT (1996) Crossing Boundaries: Knowledge, disciplinarities, and interdisciplinarities. Charlottesville, VA/London: University Press of Virginia.

Knorr Cetina K (1999) Epistemic Cultures: How the sciences make knowledge. Cambridge, MA: Harvard University Press.

Lamont M. Molnar V (2002) The study of boundaries in the social sciences. Annual Review of Sociology 28: 167-195.

Lamy J, Saint-Martin A (2011) Pratiques et collectifs de la science en régimes. Note critique. Revue d'Histoire des Sciences 64(2): 375-387.

Laredo P. Mustar P (2001) French research and innovation policy: Two decades of transformation. In: Larédo P, Mustar P (eds) Research and Innovation Policies in the New Global Economy. An international comparative analysis. Cheltenham/Northampton, MA: Edward Elgar, 447-496.

Latour B (1989) La Science en Action. Paris: Gallimard.

Latour B, Woolgar S (1979) Laboratory Life. Los Angeles, CA/London: Sage Publications.

Louvel S (2011) Des Patrons aux Managers. Les laboratoires de la recherche publique depuis les années 1970. Rennes: Presses Universitaires de Rennes.

MacCray P (2000) Large telescopes and the moral economy of recent astronomy. Social Studies of Science 30(5): 685-711.

MacCray P (2007) MBE deserves a place in the history books. Nature Nanotechnology 2(May): 259-261.

Marcovich A, Shinn T (2010a) The cognitive, instrumental and institutional origins of nanoscale research: The place of biology, In: Carrier M. Nordmann A (eds) Science in the Context of Application. Dordrecht: Springer, 221-242.

Marcovich A. Shinn T (2010b) Socio/intellectual patterns in nanoscale research: Feymman Nanotechnology Prize laureates, 1993-2007. Social Science Information 49(4): 615-638.

Marcovich A, Shinn T (2011) Where is disciplinarity going? Meeting on the borderland. Social Science Information 50(3-4): 582-606.

Mauss M (1969) Guvres 3. Cohésion sociale et division de la sociologie. Paris: Editions de Minuit.

McLean PD (2007) The Art of the Network. Strategic inferaction and patronage in Renaissance Florence. Durham, NC/London: Duke University Press.

Merz M (2006) Differenciation interne des sciences: Constructions discursives et pratiques épistémiques autour de la simulation. In: Leresche J-P. Benninghoff M, Crettaz von Roten F, et al. (eds) La Fabrique des Sciences: Des institutions aux pratiques. Lausanne: Presses Polytechniques et Universitaires Romandes, 165-182.

Moore K (2005) Scientific community: Norms. In: Restivo S (ed.) Science, Technology, and Society: An encyclopedia. New York, NY: Oxford University Press, 552-557.

Mulkay M (1976) Norms and ideologies in science. Social Science Information 15(4/5): 637-656.

Mustar P, Larédo P (2002) Innovation and research policy in France (1980-2000) or the disappearance of the Colbertist state. Research Policy 31(1): 55-72.

Nowotny H, Pestre D, Schmidt-Assman E, et al. (eds) (2005) The Public Nature of Science under Assault: Politics, markets, science and the law. Berlin: Springer.

Nowotny H, Scott P, Gibbons M (2001) Re-Thinking Science: Knowledge and the public in an age of uncertainty: London: Polity Press/Blackwell.

Padgett J, Ansell C (1993) Robust action and the rise of the Medici, 1400-1434. American Journal of Sociology 98(6): 1259-1319. 
Padget J. McLean P (2006) Organizational invention and elite transformations: The birth of partnership systems in Renaissance Florence. American Journal of Sociology 111(5): 1463-1568.

Pestre D (1990) Louis Néel, le Magnétisme et Grenoble. Récit de la création d'un empire physicien dans la province française, 1940-1965. Paris: Editions du CNRS.

Pestre D (1992[1984]) Physique et Physiciens en France, 19/8-1940. Paris: Editions des Archives Contemporaines.

Ravetz J (2005) Science and technology in the age of uncertainty. In: Restivo S (ed.) Science, Technology, and Society: An encyclopedia. New York, NY: Oxford University Press, 48 1-484.

Robinson D, Rip A, Mangematin V (2007) Technological agglomeration and the emergence of clusters and networks in nanotechnology. Research Policy 36(6): 871-879.

Rosental C (2007) Les Capitalistes de la Science: Enquête sur les démonstrateurs de la Silicon Valley et de la NASA. Paris: Editions du CNRS.

Shapin S (2010) Never Pure: Historical studies of science as if it was produced by people with bodies, situated in time, space, culture, and society, and struggling for credibility and authority. Baltimore, MD; Johns Hopkins University Press.

Shapira P. Wang J (2010) Follow the money. Nature 468: 627-628.

Shinn T (2005) New sources of radical innovation: Research technologies, transversality and distributed learning in a post-industrial order. Social Science Information 44(4): 731-764.

Shinn T (2006) Differentiation and complementarity: Boundaries and boundary crossing in science and industry. Communication at the 'Science in the context of application: Transformations of academic research" conference, Zentrum für interdisziplinäre Forschung, Universität Bielefeld, 27 October.

Shinn T (2008) Research Technology and Cultural Change: Instrumentation, genericity, transversality: Oxford: The Bardwell Press.

Shinn T, Ragouet P (2005) Controverses sur la Science: Pour une sociologie transwersaliste de l'activité scientifique, Paris: Raisons d'Agir.

Shrum W, Genuth J, Chompalov I (2007) Structures of Scientific Collaboration. Cambridge, MA London: MIT Press.

Slaughter S, Rhoades G (2005) From "endless frontier" to "basic science for use"; Social contracts between science and society. Science. Technology and Human Values 30(4): 536-572.

Spillman L (2007) Culture. In: Ritzer G (ed.) Blackwell Encyclopedia of Sociology. Oxford: Blackwell Reference Online, Blackwell Publishing.

Star SL. Griesemer J (1989) Institutional ecology, 'translation' and boundary objects: Amateurs and professionals in Berkeley's museum of vertebrate zoology, 1907-39. Social Studies of Science 19(3): 387-420.

Strauss AL, Rainwater L (1962) The Professional Scientist: A study of American chemists. Chicago, IL: Aldine.

Surowiecki J (2004) Bring on the nanobubble. The New Yorker 80(4): 68.

Swidler A (1986) Culture in action: Symbols and strategies. American Sociological Review 51(2): 273-286.

Swidler A (2001) What anchors cultural practices, In: Schatzki T, Knorr Cetina K, Von Savigny E (eds) The Practice Turn in Contemporary Theory: London/New York, NY: Routledge, 74-92.

Taylor CA (1998) Feuding communities and the feudalism of science: Democratizing the community and/of science. In: Hogan M (ed.) Rhetoric and Community: Studies in unity and fragmentation. Columbia, SC: University of South Carolina Press, 284-291.

Thompson EP (1971) The moral economy of the English crowd in the eighteenth century. Past \& Present 50: 76-136.

Traweek S (1988) Beamtimes and Lifetimes: The world of high energy physicists. Cambridge, MA London: Harvard University Press. 
Vaughan D (1996) The Challenger Launch Decision: Risky technology; culture, and deviance at NASA. Chicago, IL/London: University of Chicago Press.

Vinck D (2010) The 'enterprise of science': Construction and reconstruction of social capital around nano R\&D. International Journal of Nanotechnology 7(2/3): 121-136.

Vinck D, Galliee P, Jouvenet M. et al. (2007) Dynamique technologique controversée et débat démocratique: Le cas des micro et nanotechnologies. In: Goujon P. Lavelle S (eds) Technique, Communication et Société: A la recherche d'un modèle de gouvernance. Namur: Presses Universitaires de Namur, 247-266.

Vinck D, Hubert M. Jouvenet M. et al. (2006) Culture de la différence et pratiques de l'articulation entre chercheurs en micro- et nanotechnologie. In: Leresche J-P. Benninghoff $\mathrm{M}$. Crettaz von Roten F, et al. (eds) La Fabrique des Sciences: Des institutions aux pratiques, Lausanne: Presses Polytechniques et Universitaires Romandes, 147-163.

Vinck D, Zarama G (2007) La fusion de laboratoires: Processus de gestion et constitution d'une entité pertinente de l'activité scientifique. Revue d'Anthropologie des Connaissances 1(2): 267-296.

Wenger E (1998) Communities of Practice: Learning, meaning, and identity. New York, NY: Cambridge University Press.

Whitley R (1984) The Intellectual and Social Organization of the Sciences. Oxford: Clarendon Press.

Winch P (1990[1958]) The Idea of a Social Science and Its Relation to Philosophy. London: Routledge.

Zarama G, Vinck D (2011) Façonnage des espaces de travail d'un collectif de recherche en micro et nanotechnologies. Terrains \& Travaux 18; 61-80.

\section{Author biography}

Morgan Jouvenet is a researcher at the Centre National de la Recherche Scientifique, and a member of the Printemps laboratory (CNRS/Université de Versailles Saint-Quentin-en-Yvelines, France). His main domains of interest are the sociology of science, the sociology of work and professions. and the sociology of art. His book on popular music production, Rap. Techno, Electro... Le musicien entre travail artistique et critique sociale (Paris: Editions de la Maison des Sciences de IHomme, 2006) received the Young Sociologist Award from the Association Internationale des Sociologues de Langue Française (AISLF) in 2008. 